\title{
$\begin{array}{llllllllllll}\text { B } & \text { I } & \text { B } & \text { L } & \text { I } & \text { O } & \text { G } & \text { R } & \text { A } & \text { F } & \text { I } & \text { A }\end{array}$
}

ROCZNIKI TEOLOGICZNE

$\underline{\text { Tom LXVI, zeszyt } 7-2019}$

PIOTR KOPIEC

DOI: https://dx.doi.org/10.18290/rt.2019.66.7-16

\section{BIBLIOGRAFIA PRACOWNIKÓW INSTYTUTU EKUMENICZNEGO KUL W 2018 ROKU}

KS. PROF. DR HAB. MAREK J A G O D Z I Ń S K I

I. MONOGRAFIE

- Eschatologia dzisiaj, (Teologia w Dialogu, t. 18), Lublin: Wydawnictwo KUL, Lublin 2018, ss. 128. ISBN 978-83-8061-600-4.

II. ARTYKUŁY NAUKOWE

- Trynitarno-komunijne wymiary misji Kościoła według encykliki Jana Pawła II Redemptoris missio, w: Pamięć i zobowiązanie. W hołdzie wobec myśli świętego Jana Pawła II, red. Wojciech Wojtyła, Radom: Wydawnictwo Diecezji Radomskiej AVE 2017, s. 43-54. ISBN 978-83-61147-19-0.

- Maryja w komunijnym planie Ojca, ,Studia Sandomierskie. Teologia - Filozofia - Historia" 24 (2017), s. 171-181.

- Komunijna pieczęć Niepokalanego Poczęcia Maryi, „Salvatoris Mater” 19 (2017) nr 1-4, s. 307-317.

- Konsekwencje współczesnych zmian dla teologii i Kościoła, „Roczniki Teologiczne" 65 (2018), z. 7, s. 5-20.

- Zwiastowanie - komunijny przełom w historii zbawienia, „Teologia w Polsce” 12 (2018), nr 1, s. 15-25.

- Mother of the Communion of the Incarnation, „Rocznik Teologii Katolickiej” 17 (2018), nr 1, s. 167-181.

Dr hab. Piotr KopIec, prof. KUL - Katolicki Uniwersytet Lubelski Jana Pawła II, Wydział Teologii, Instytut Nauk Teologicznych, Sekcja Ekumenizmu, Katedra Teologii Protestanckiej; adres do korespondencji — e-mail: petrko@kul.pl. 
- Encyklika Redemptoris missio jako szczyt papieskiego nauczania o działalności misyjnej Kościoła, „Studia Elbląskie” 19 (2018), s. 327-338.

II. PRZEKŁADY

- Anton ŠTRUKELJ, „Oczyszczenie pamięci” („Die Reinigung des Gedächtnisses”. Rückblick auf die Vergebungsbitte der Kirche im Jubiläumsjahr 2000, „Kirche heute” 6 (2018), s. 13-15), „Communio. Międzynarodowy Przegląd Teologiczny" 3 (2016), s. 67-75.

Ks. DR hab. PrZemysŁaw Kantyka, Prof. KUL

\section{ARTYKUŁY NAUKOWE}

- The Challenges and Opportunities of Moral Issues in View of Mutual Recognition, w: Just Do It?! Recognition and Reception in Ecumenical Relations/Anerkennung und Rezeption im ökumenischen Miteinander. Proceedings of the 19th Academic Consultation of the Societas Oecumenica/Tagungsbericht der 19. Wissenschaftlichen Konsultation der Societas Oecumenica , red. Dagmar Heller, Minna Hietamäki, Leipzig: Evangelische Verlagsanstalt 2018, s. 119-134. ISBN 978-3-374-05362-9.

- Instytut Ekumeniczny, w: 100 lat teologii na KUL, red. Sławomir Nowosad, Jacenty Mastej, Lublin: Wydawnictwo KUL 2018, s. 153-163. ISBN 978-838061-558-8.

- Anglikanie i metodyści znów razem? Odnowienie jedności kościelnej między anglikanami i metodystami w Wielkiej Brytanii wedle dokumentu «Misja i Służba w Przymierzu», „Roczniki Teologiczne” 65 (2018), z. 7, s. 105-118.

- Towards common Christian response to the anthropological challenges? Pope's Francis encyclical letter Laudato si' and the Justice, Peace and Integrity of Creation programme of the World Council of Churches, „Studia Oecumenica” 18 (2018), s. 25-40.

- „Nieważne i niebyłe”. Problem uznania przez Rzym ważności święceń anglikańskich, w: Sukcesja i urząd biskupa. Perspektywa polskokatolicka i rzymskokatolicka, red. Paweł Rabczyński, Olsztyn: Wydawnictwo Uniwersytetu Warmińsko-Mazurskiego 2018, s. 79-87. ISBN 978-83-8100-141-0.

- Communicatio in spiritualibus: Sharing Spiritual Activity and Resources with our Separated Brethren according to the Ecumenical Directory, „Ecumeny and Law" 6 (2018), s. 51-61.

II. HASŁA ENCYKLOPEDYCZNE

- Europejskie Stowarzyszenie Badań Ekumenicznych „Societas Oecumenica”, w: Encyklopedia 100-lecia KUL, t. 1, red. Edward Gigilewicz i in., Lublin: Wydawnictwo KUL: 2018, s. 213-214. ISBN 978-83-8061-611-0. 
III. WPROWADZENIA

- Przedmowa, w: Danny Steyne, Przyjaźnili się z Bogiem. Mieszkam w niebie... tylko pracuję na ziemi, Lublin: Rhema 2018, s. 5-6. ISBN 978-83-937391-0-3.

IV. RECENZJE WYDAWNICZE

- Piotr JASKÓ£A, Ut sint unum. Wprowadzenie do ekumenizmu. Opole: Redakcja Wydawnictw Wydziału Teologicznego Uniwersytetu Opolskiego 2018, ss. 213. ISBN 978-83-65860-24-8.

V. SPRAWOZDANIA

- Działalność naukowa Instytutu Ekumenicznego KUL w 2017 roku, „Roczniki Teologiczne" 65 (2018), z. 7, s. 195-210.

DR HAB. PIOTR K O P I E C

\section{ARTYKUŁY NAUKOWE}

- Ekumeniczna krytyka kapitalizmu, „Roczniki Teologiczne” 65 (2018), z. 7, s. 151-166.

- Projekt radykalizacji Reformacji: Ulricha Duchrowa teologiczna krytyka współczesnego porządku społecznego i politycznego, „Kultura i Społeczeństwo” (Polska Akademia Nauk) 62 (2018), nr 1, s. 187-203.

- Ecumenical Ambiguities: The Case of the Ecumenical Association of Third World Theologians, „Studia Oecumenica” 18 (2018), s. 41-52.

- Powołanie jako kategoria reformacyjnej nauki społecznej, „Człowiek. Kultura. Teologia" 4 (2018), s. 58-75.

- Teologia Minjung jako problem nie tylko ekumeniczny, „Kieleckie Studia Teologiczne" 7 (2018), s. 117-131.

- Wyzwania ponowoczesnego świata w perspektywie ekumenicznej, „Nurt SVD” 144 (2018), nr 2, s. 167-182.

II. SPRAWOZDANIA

- Bibliografia pracowników Instytutu Ekumenicznego KUL (rok 2017), „Roczniki Teologiczne" 65 (2018), z. 7, s. 199-202.

- „Z prawdziwego skarbu Kościoła(ów). Wspólnie odkrywając na nowo Ewangelię”. Konferencja ekumeniczna Międzynarodowej Wspólnoty Ekumenicznej, Wittenberga, 21-28 sierpnia 2017 roku, „Roczniki Teologiczne” 65 (2018), z. 7, s. 191-194.

- Chrześcijaństwo i ekumenizm w erze migracji. XX konsultacje akademickie Europejskiego Stowarzyszenia Badań Ekumenicznych Societas Oecumenica, „Nurt SVD” 144 (2018), nr 2, s. 375-383.

III. RECENZJE

- Św. Bazyli wielki jako wzór lidera Kościoła, [Rec.: Nicu DuMITRAȘCU, Basil the Great: Faith, Mission and Diplomacy in the Shaping of Christian Doctrine, New York: Routledge 2018, ss. 216], ,Kieleckie Studia Teologiczne” 17(2018), s. 311-314. 
- Teologiczne interpretacje wyzwań współczesności, [Rec.: Marek JAGODZIŃSKI (red.), Kwestie dyskutowane w teologii dzisiaj, Radom: Wydawnictwo Diecezji Radomskiej 2017, ss. 424], „Roczniki Teologiczne” 65 (2018), z. 7, s. 186-190.

PROF. DR HAB. KRZYSZTOF L E Ś N I E W S K I

\section{MONOGRAFIE}

- Las enfermedades del Espíritu. Diagnóstico y tratamiento en clave cristiana, tradujo M. Huarte Luxán, Salamanca: Ediciones Sígueme 2017, ss. 237. ISBN 978-84-301-1975-2.

- „W sobie samym znaleźliśmy wyrok śmierci: aby nie ufać sobie samemu, lecz Bogu". Metanoiczno-soteriologiczne przesłanie Wielkiego kanonu św. Andrzeja z Krety, Lublin: Wydawnictwo Prawosławnej Diecezji Lubelsko-Chełmskiej 2017, ss. 456. ISBN 978-83-939081-9-6.

III. ARTYKUŁY NAUKOWE

- The Great Canon of St. Andrew of Crete. Scriptural, Liturgical and Hesychastic Invitation for an Encounter with God, „Vox Patrum” 38 (2018), t. 69, s. 429-447.

- Człowiek jako osoba w antropologii mistycznej Włodzimierza Łosskiego, „Roczniki Teologiczne” 65 (2018), z. 7, s. 53-64.

- Refleksje nad śmiercią i Sądem Ostatecznym w Wielkim kanonie św. Andrzeja z Krety, w: W drodze do brzegu życia, t. XVI, red. Elżbieta Krajewska-Kułak, Cecylia Regina Łukaszuk, Jolanta Lewko, Wojciech Kułak, Białystok: Uniwersytet Medyczny w Białymstoku. Wydział Nauk o Zdrowiu 2018, s. 59-68. ISBN 978-83-946571-9-2.

- Kościół jako ikona misterium Trójcy Przenajświętszej w teologii prawosławnej, w: Wyjątkowość Kościoła katolickiego, red. Andrzej A. Napiórkowski OSPPE, Kraków 2018, s. 76-89. ISBN 978-83-7580-529-1.

Ks. DR HAB. SŁAWOMIR P A W Ł O W S K I SAC, PROF. KUL

\section{ARTYKULY NAUKOWE}

- Pietyzm XVII wieku jako protestancka forma Nowej Ewangelizacji, „Roczniki Teologiczne" 65 (2018) s. 119-127.

- Chrzest - wolność - miłość. Ekumenizm duchowy X i XI Zjazdu Gnieźnieńskiego, „Studia Oecumenica 18 (2018) s. 53-67.

II. REDAKCJA I WSPÓŁREDAKCJA PUBLIKACJI ZBIOROWYCH

- Daż do sprawiedliwości (Pwt 16,20). Materiały na Tydzień Modlitw o Jedność Chrześcijan 18-25 stycznia i cały rok 2019, red. Andrzej Gontarek, Sławomir Pawłowski, Edward Puślecki, Doroteusz Sawicki, Kalina Wojciechowska, Warszawa: Rada ds. Ekumenizmu Konferencji Episkopatu Polski i Polska Rada Ekumeniczna 2018. ISSN 0208-9424. 
- Ekumeniczna postylla. Na pierwszy rok kościelny po obchodach 500-lecia Reformacji (2017/2018), red. merytoryczna Grzegorz Brudny, Andrzej Konachowicz, Sławomir Pawłowski, red. językowa Elżbieta Żurek, Sławomir Jacek Żurek, Lublin: Towarzystwo Naukowe KUL 2018, ss. 268. ISBN 978-83-7306834-6.

III. HASŁA ENCYKLOPEDYCZNE

- Tygodnie Ekumeniczne, w: Encyklopedia 100-lecia KUL, t. 2, red. Edward Gigilewicz i in., Lublin: Wydawnictwo KUL 2018, s. 495. ISBN 978-83-8061612-7.

KS. DR HAB. TOMASZ S I E M I E N I E C

I. MONOGRAFIE

- Teologiczna rola „ludzi” (hoi anthropoi) w Apokalipsie Janowej, (Biblioteka Kieleckich Studiów Teologicznych, t. 16), Kielce: Wydawnictwo JEDNOŚĆ 2018, ss. 682. ISBN 978-83-7971-928-0.

II. ARTYKULY POPULARNONAUKOWE

- Nasze święte rodziny, ,Współczesna Ambona” 46 (2018), nr 1, s. 51-56.

- Trąd ciała i duszy, „Współczesna Ambona” 46 (2018), nr 1, s. 118-121.

- Szansa na nawrócenie, „Współczesna Ambona” 46 (2018), nr 2, s. 6-9.

- Miłość, która przynosi owoc, „Współczesna Ambona” 46 (2018), nr 2, s. 114-117

- Należymy do owczarni Pana, „Współczesna Ambona” 46 (2018), nr 3, s. 81-84.

- Naśladowanie, które prowadzi do zbawienia, „Współczesna Ambona” 46 (2018), nr 3, s. 151-154. 